\title{
A RATIONAL APPROACH TO THE DESIGN OF AERATED SEWAGE LAGOONS
}

\author{
Edward F. Pohl
}

\author{
October 1970
}

U. S. Any on: 
The findings in this report are not to be construed as an official Department of the Army position unless so designated by other authorized documents.

Destroy this report when no longer needed. Do not return it to the originator. 


\section{A RATIONAL APPROACH TO THE DESIGN OF AERATED SEWAGE LAGOONS}

Edward F. Pohl

October 1970

DA TASK 1 TO62112A13001

CORPS OF ENGINEERS, U.S. ARMY

COLD REGIONS RESEARCH AND ENGINEERING LABORATORY

HANOVER, NEW HAMPSHIRE 


\section{PREF ACE}

This report was prepared by Mr. Edward F. Pohl, Chief, Sanitary Engineering Section, Alaska District, U.S. Army Corps of Engineers, as a guide for design work on the subject topic. It was reviewed by USA CRREL project engineers and its general value as a stateof-the-art summary recognized. Its publication as a USA CRREL Special Report is intended to supplement information available in standard reference works as well as other reports and monographs in the USA CRREL series. The report was reviewed, and its publication recommended, by Mr. Sherwood C. Reed, Research Sanitary Engineer, USA CRREL.

The report is published under DA Task 1T062112A13001, Cold Regions Research Applied Research and Engineering.

The contents of this report are not to be used for advertising, publication, or promotional purposes. Citation of trade names does not constitute an official endorsement or approval of the use of such commercial products. 


\section{CONTENTS}

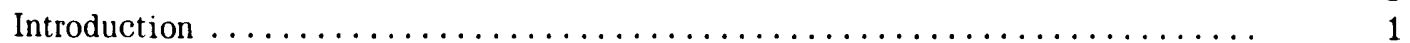

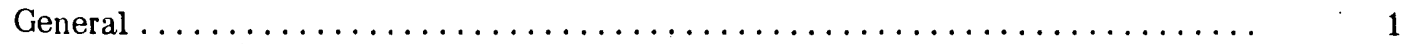

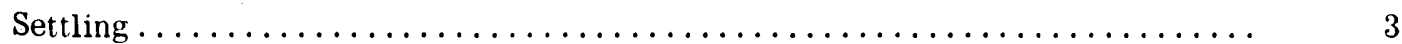

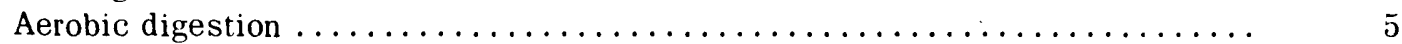

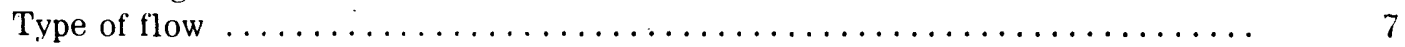

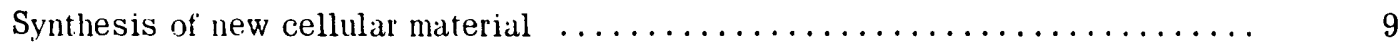



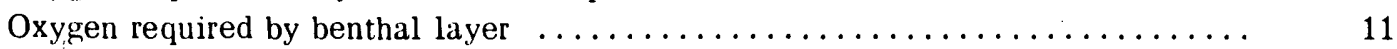

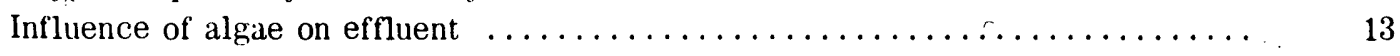

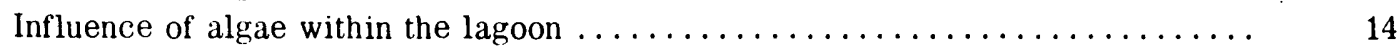



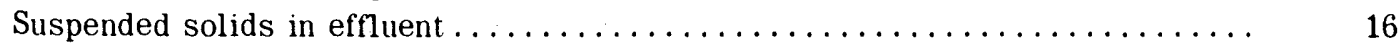

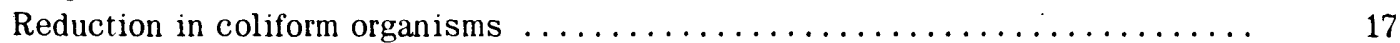

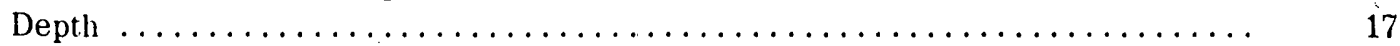

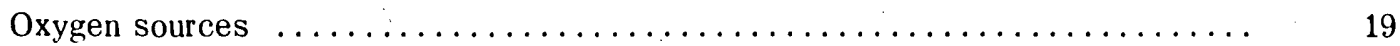

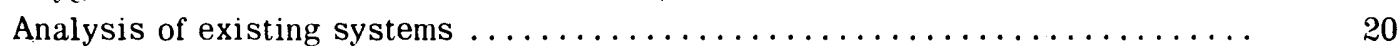

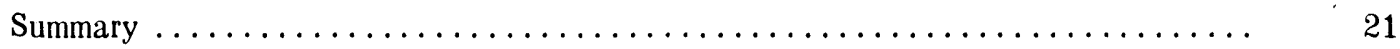

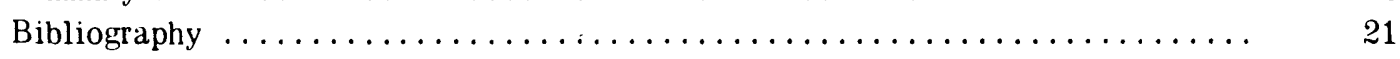

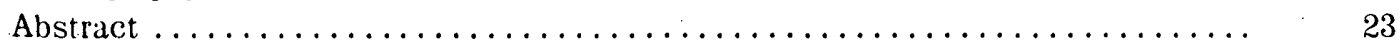

\section{ILLUSTRATIONS}

Figure

1. Schematic of aerated lagoon using tubing for aeration $\ldots \ldots \ldots \ldots \ldots \ldots$

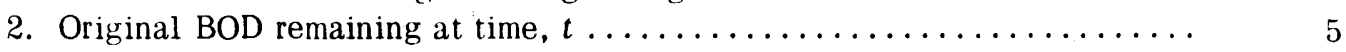

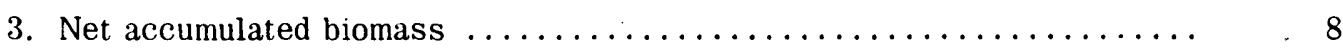

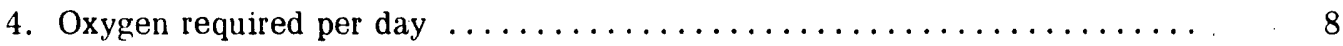

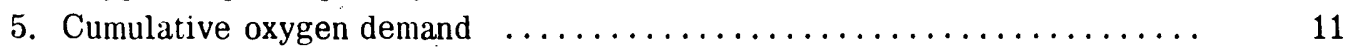

$\begin{array}{ll}\text { 6. Effect of BOD on the concentration of algal cells in continuous cultures. . } & 15\end{array}$

7. BOD characteristics of biological sludges .................. 16

8. Observed mean pond temperature $/ 100 \mathrm{ml}$ in a single falcultative pond as a function of time and temperature $\ldots \ldots \ldots \ldots \ldots \ldots \ldots \ldots \ldots \ldots$

9. Effect of water temperature on values of $K_{b}$ for death rate of coliform

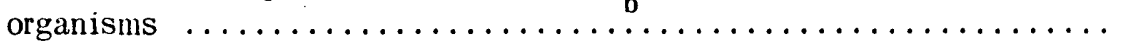
8 (1) 11 16

\section{TABLES}

Table

I. Reduction in supernatant suspended solids at a depth of 12 in. due to sedimentation in a quiescent facultative stabilization pond ......... 4

II. Comparison of biological systems $\ldots \ldots \ldots \ldots \ldots \ldots \ldots \ldots \ldots \ldots$

III. Gas production in a facultative pond at a point where the benthic BOD load

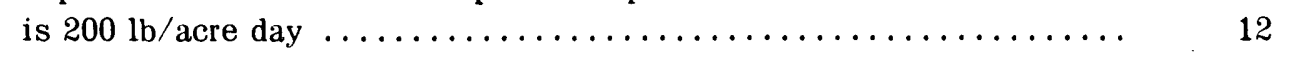

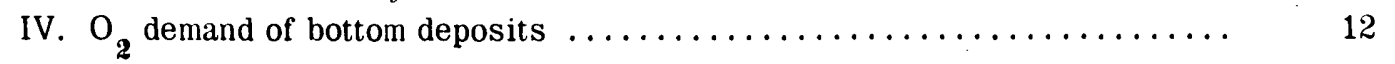




\title{
A RATIONAL APPROACH TO THE DESIGN OF AERATED SEWAGE LAGOONS
}

by

\author{
Edward F: Pohl
}

\section{Introduction}

New Alaska State Water Quality Standards, formulated in accordance with the Federal Water Quality Act of 1965 (Public Law 89-234) and the recent nationwide effort to achieve pollution control, dictate a need for more efficient waste treatment facilities serving Federal establishments in Alaska. The President, by Executive Order No. 11,288 dated 2 July 1966, has directed the Federal establishment to assume a leading role in this program.

An orderly program for upgrading waste treatment facilities serving military establishments in Alaska has been developed. To comply with State Water Quality Standards, the need has emerged for inexpensive treatment plants capable of producing an effluent of "secondary treatment" quality with a minimum of maintenance and operational skills. Alaskan climatic conditions require most conventional treatment systems to be heated and housed. Many of the military establishments to be served are small and isolated. 'Treatment using lagoons holds promise for accomplishing the objectives described above.

The Air Force recognized the need and initiated an interservice agreement with the Arctic Health Research Center, U.S. Public Health Service, College, Alaska, in 1964 to install and observe an aerated lagoon at Eielson AFB near Fairbanks. The studies, conducted under the direction of Lt. Leroy Reid, used the Air-Aqua System described by Meyer ${ }^{11}$ and Hurwitz ${ }^{9}$ as a source of oxygen. The studies demonstrated that treatment facilities capable of meeting Air Force objectives at a cost substantially below that of more conventional facilities were technically feasible. The remaining need is to define and evaluate the various processes going on in the system in order to develop a rational basis for design.

The purpose of this study is to build a design skeleton out of the principles, as they are presently known, which can be fleshed out with additional research. The skeleton turns out to be reasonably complete. : The equations were developed from basic sanitary engineering theory, and if used with eaution should permit design of functioning units with a reasonable expectation that they will perform as desired. Additional research to evaluate the equations and define the constants more closely should result in increased design efficiency and further reduction in cost.

\section{General}

Waste stabilization lagoons can generally be divided into three classifications depending upon whether they use aerobic processes, anaerobic processes or a combination of both to stabilize wastes. The use of anaerobic ponds in Australia has been extensively reported.? Anaerobic ponds have also been used in this country, usually for wastes which are concentrated and warm, and most 
often for meat packing wastes. The attraction of these ponds lies in the high organic loadings potentially feasible. Oswald ${ }^{16}$ has reported on a pond located at Woodland, California, which successfully stabilizes a summer load of about $700 \mathrm{lb}$ Biochemical Oxygen Demand (BOD) per acre per day.

Oswald and Gotaas ${ }^{17}$ have formulated design criteria for completely aerobic high rate lagoons using algae as a source of oxygen. These lagoons are preceded by a clarifier to remove settleable solids and are completely mixed. Shallow depths (normally less than a foot) are used with short detention times. They are designed to support a large population of algae as a primary source of oxygen. BOD loadings up to $200 \mathrm{lb}$ per acre per day can be stabilized in mild sunny climates.

The conventional facultative lagoon is composed of an anaerobic bottom zone separated from an aerobic upper zone by a thermocline. Algae are utilized as the major source of oxygen in the aerobic zone. Researchers at Clemson University in South Carolina have shown that conventional lagoons are actually on a volume basis $75 \%$ anaerobic. ${ }^{7}$

Oswald $^{15}$ has shown that algae are capable of producing up to $200 \mathrm{lb}$ of oxygen per acre per day with adequate temperature, illumination and nutrients. However, this ability is reduced to about $50 \mathrm{lb}$ oxygen per acre per day for an unmixed pond $4 \mathrm{ft}$ deep. The oxygen in a facultative lagoon is supplied both by algae and by surface reaeration. Also the oxygen demand is greater at the inlet end of the lagoon. However, empirical observation of pond failures above a loading of approximately $50 \mathrm{lb}$ BOD per acre day due to the inability of the system to maintain dissolved oxygen in the aerobic zone led to adoption of $\mathbf{4 0} \mathrm{lb}$ per acre per day as a design parameter for facultative lagoons. This has been reduced to $20 \mathrm{lb}$ per acre per day in cold climates to compensate for decreased algal metabolism at lower temperatures and the added BOD load experienced in the spring.

Recently lagoons using mechanical or diffused aeration have been used to avoid the problems associated with the use of algae which are an undependable, inefficient source of oxygen in northern climates. Depending upon recycle rates, amount of turbulence and mixing, and efficiency of the oxygen transfer equipment, aerated lagoons may vary in nature from the inefficient, long detention time, facultative lagoon to turbulent, completely mixed high rate aerobic lagoons. The percentage of the total organic loading stabilized anaerobically is determined by the amount of turbulence available to maintain the solids in suspension.

The aerator devices normally used are surface units which achieve oxygen transfer by turbulence. They may be floating or suspended over the surface of the lagoon on a support. The result is a completely mixed system. Rational approaches to the design of these facilities have been outlined by Eckenfelder and $0^{\prime}$ Connor, ${ }^{6}$ Thimsen, ${ }^{26}$ and Eckenfelder. ${ }^{5}$. Digestion is assumed to be all aerobic with complete mixing. The relationships used are those developed for other completely mixed, $100 \%$ aerobic, activated sludge processes.

Organic loading, and thus detention time, is limited by oxygen transfer capability. As the detention time is reduced, recycle becomes necessary to return sludge washec' out of the system and to maintain adequate mixed liquor volatile suspended solids (MLVSS) concentrations. A typical design for an aerated lagoon using standard surface aerators for a typical domestic waste (BOD = $250 \mathrm{mg} / 1, k_{1}=0.23 @ 25^{\circ} \mathrm{C}$ ) gives $70 \%$ removal with a detention time of 4.5 days. ${ }^{6}$ Recycle is not normally practiced with these units. When increased efficiencies are desired, a second cell may be provided in series with the first. The surface type aerators are not suitable for use in cold climates because the aerator unit tends to ice up, creating maintenance problems. Also, the high level of turbulence results in rapid dissipation of heat from the liquid body, resulting in extensive freezing.

A device recently placed on the market promises to avoid some of these problems. It consists of small diameter polyethylene tubing laid on the bottom of the lagoon in a grid pattern. The tubing 


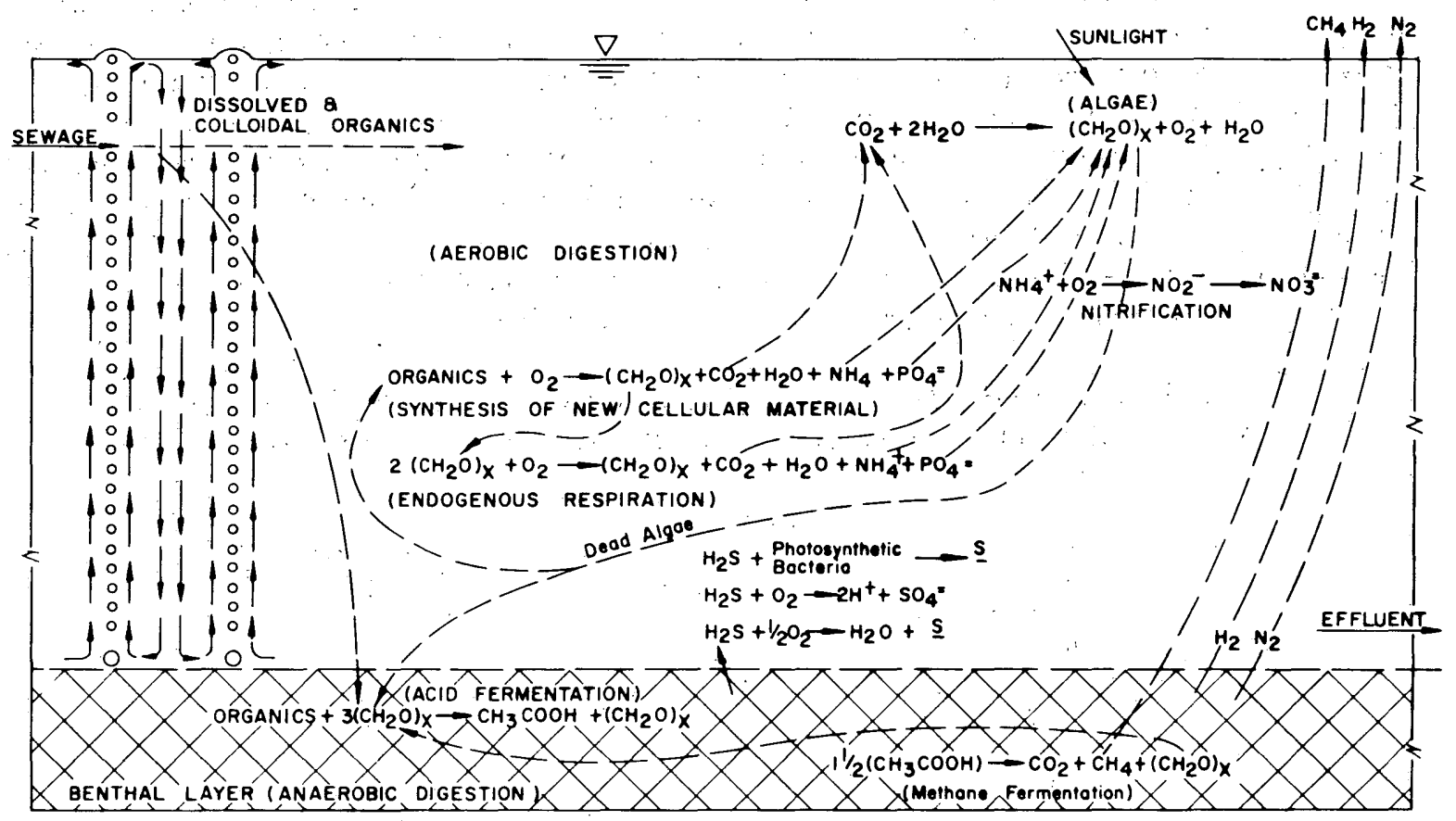

Figure 1. Schematic of aerated lagoon using tubing for aeration.

is formed with a lead keel on the bottom to permit it to remain upright. Tiny slits of uniform size are precut in the top to permit air to escape. The grid is connected to an air compressor located on the bank of the lagoon. The resultant stream of small bubbles. serves as the oxygen transfer device and imparts a gentle motion to the adjacent column of water. Partial ice cover forms over the surface of the lagoon during cold weather to conserve heat and protect the oxygen transfer device from the elements.

A pilot plant utilizing this method of oxygen transfer was installed at Eielson AFB, 30 miles south of Fairbanks, Alaska, in 1964. The results have been reported extensively by Reid. ${ }^{19} .2022$ Based upon the results observed by Reid, the F.AA has also installed similar lagoons at Northway, Bethel and Cold Bay. The results at Northway and Bethel have been monitored and reported by Reid. ${ }^{22}$ Lagoons using this type of aeration equipment have also been installed at Harvey, North Dakota; Norway, Maine; and Regina, Saskatchewan. McKinney ${ }^{10}$ has reported on the performance of lagoons at Lee's Summit and Raytown, Missouri, which utilize the tubing described herein as a source of oxygen.

The major processes occurring in a lagoon utilizing tubing as the primary source of oxygen appear to be similar to those occurring in a conventional facultative lagoon (Fig. 1).

\section{Settling}

Air is normally introduced at the rate of from 1 to $3 \mathrm{ft}^{3}$ per minute per $100 \mathrm{ft}$ of tubing. The resulting vertical stream of bubbles imparts a velocity to the adjacent column of water. This establishes a gentle mixing action within the zone between adjacent tubes as shown in Figure 1 . The resulting velocities are reported $d^{23}$ to be less than $1 \mathrm{ft} / \mathrm{sec}$ and are not rapid enough to maintain all of the settleable solids in suspension. Reid ${ }^{22}$ reports an $8-$ to 10 -in. buildup of sludge at the inlet to the Eielson lagoon during winter 1965-1966 under heavy loading conditions. Partial clogging of the air lines occurred, which the author attributed to the weight of solids 
deposited over the tubing. This would demonstrate the inability of the tubing to maintain solids in suspension immediately over the tubing. The size of material maintained in suspension between adjacent tubes would be expected to be a function of spacing. Incoming organic materials in a waste are composed of dissolved, colloidal and settleable fractions. Primary treatment of a domestic waste normally settles out approximately $40 \%$ of the total BOD indicating this comprises the settleable fraction. In a quiescent facultative lagoon $50 \%$ of the suspended solids have been observed to settle out in 15 minutes and $85 \%$ removal occurs within 24 hours. ${ }^{15}$. Much of the colloidal and soluble fractions are converted to new cellular material. Most of this also eventually settles into the anaerobic zone on the bottom in a quiescent lagoon (see Table 1).

Table I. Reduction in supernatant suspended solids at a depth of $12 \mathrm{in}$. due to sedimentation in a quiescent facultative stabilization pond. (From Oswald. ${ }^{15}$ )

\begin{tabular}{lcc}
$\begin{array}{c}\text { Time } \\
(\mathrm{hr})\end{array}$ & $\begin{array}{c}\text { Suspended } \\
\text { solids } \\
(\mathrm{mg} / \text { liter })\end{array}$ & $\begin{array}{c}\text { Reduction } \\
(\%)\end{array}$ \\
\hline 0 & 225 & 0 \\
0.25 & 120 & 47 \\
0.50 & 96 & 57 \\
1.0 & 90 & 60 \\
2.0 & 84 & 63 \\
4.0 & 60 & 73 \\
8.0 & 44 & 81 \\
24.0 & 33 & 85 \\
48.0 & 29 & 87 \\
\hline
\end{tabular}

For a lagoon aerated with tubing, the fraction maintained in suspension and digested aerobically would be larger than that in a facultative lagoon. An accurate estimate of the fraction settling into the anaerobic bottom layer will have to be determined by actual measurement. In the interim, an attempt has been made to bracket the maximum and minimum percentage of the incoming BOD expected to be digested aerobically and the resulting curves have been plotted throughout the study using both values. The values were determined as follows:

The normal domestic waste has a 5-day BOD of approximately $200 \mathrm{mg} / 1$ derived from a per capita contribution of $0.17 \mathrm{lb}$ BOD and $100 \mathrm{gal}$ of waste per capita per day

$$
\frac{0.17(10)^{6}}{8.33(100)}=204 \mathrm{mg} / \mathrm{l}
$$

The ultimate BOD at $k_{1}=0.20$ is $226 \mathrm{mg} / 1$. Assuming one third of the incoming BOD is settled out, the fraction digested aerobically is

$$
0.67(226)=150 \mathrm{mg} / \mathrm{l} \text {. }
$$

This is a minimum value which is not likely to be attained. A slightly stronger waste (ultimate BOD $=250 \mathrm{mg} / \mathrm{l}$ ), none of which settles out, was assumed for the maximum condition. For the military installations under discussion, the actual amount of incoming BOD stabilized aerobically should lie between these values.

Figure 2 is a plot of ultimate first stage BOD remaining to be stabilized aerobically vs time for an ultimate BOD of $150 \mathrm{mg} / 1$ and $250 \mathrm{mg} / 1$ at winter temperature $\left(0.5^{\circ} \mathrm{C}\right)$ and summer temperature $\left(20^{\circ} \mathrm{C}\right)$. Two values for the deoxygenation constant $\left(k_{1}\right)$ were assumed $\left(0.28\right.$ and 0.20 at $\left.20^{\circ} \mathrm{C}\right)$ as described in the following section. 


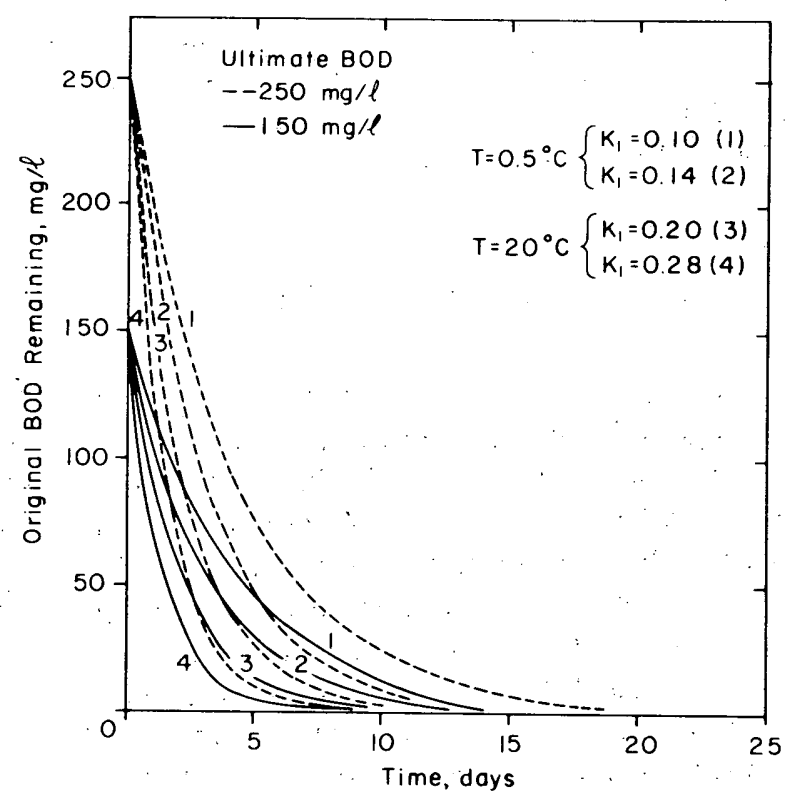

Figure 2. Original $B O D$ remaining at time, $t$.

\section{Aerobic digestion}

Streeter and Phelps, ${ }^{24}$ some 40 -odd years ago, proposed the concept that the rate of oxidation of organic materials is a first order or monomolecular reaction. The monomolecular rate concept can be expressed as:

$$
\frac{d L}{d t}=-K L
$$

where

$$
\begin{aligned}
L & =\text { BOD concentration } \\
t & =\text { time } \\
K & =\text { reaction coefficient to the base } e .
\end{aligned}
$$

From this, the basic equation for BOD removal can be derived.

$$
Y=L\left(1-10^{-k_{1} t}\right)
$$

where

$$
\begin{aligned}
Y & =\text { BOD utilized in time } t \\
L & =\text { ultimate first stage BOD } \\
t & =\text { time, days } \\
k_{1} & =\text { deoxygenation constant } \\
& =\text { reaction coefficient to the base } 10 \\
& =K / 2.3 .
\end{aligned}
$$


As originally derived, $k_{1}$ was thought to be a constant and equal to 0.1 . However, in order for $k_{1}$ to be a constant, a constant percentage of the remaining substrate must be utilized in each unit time $t$. This assumes all of the materials present are equally available to the organisms. Eckenfelder ${ }^{6}$ expresses the true relationship as

$$
-\frac{d L}{d t}=K_{1} L_{1}+K_{2} L_{2}+K_{3} L_{3} \ldots+K_{\mathrm{n}} L_{\mathrm{n}}
$$

where the subscripts refer to organic materials of varying resistance to biological degradation. Phelps, Moore, Orford and Ingram ${ }^{14}$ and others have shown that the $k_{1}$ value decreases as the observation period increases. Values as high as 0.4 have been observed for domestic settled wastes at $20^{\circ} \mathrm{C}$ when determined over a 36 -hour period. ${ }^{18}$ Hoover et al. ${ }^{8}$ working with milk wastes, demonstrated that whenever a monomolecular reaction rate is encountered with a $k_{1}$ value equal to 0.10 at $20^{\circ} \mathrm{C}$, the reaction is solely one of endogenous respiration. This appears to be a good explanation for the common observation that the deoxygenation constant approaches 0.10 at the far end of the curve. Orford and Ingram $^{14}$ concluded that the value of $k_{1}$ for a domestic waste is about 0.25 for a 3-day observation period decreasing gradually to about 0.11 for a 14 -day observation period. The curves in Figure 2 demonstrate that $70 \%$ or more of the initial BOD is removed within the first 5 days. To be accurate, the BOD equation should show $k_{1}$ as a function of time. For the purposes of this study, short-term $k_{1}$ values will be used. The error introduced should be tolerable until all of the constants have been evaluated more accurately.

The Michaelis-Menton equation can be used to show that the $k_{1}$ value is also a function of number of organisms present. ${ }^{18}$. Eckenfelder ${ }^{6}$ lists the following table of $k_{1}$ values:

Table II. Comparison of biological systems. (From Eckenfelder. ${ }^{6}$ )

\begin{tabular}{|c|c|c|c|c|}
\hline System & Solids & Turbulence & Oxygen conc & $\begin{array}{c}\text { Range } \\
k_{1}\end{array}$ \\
\hline Unaerated lagoon & Low & None & None & $0.20-0.10$ \\
\hline BOD bottle & Low & None & High & $0.10-0.30$ \\
\hline Natural rivers & $\begin{array}{l}\text { Low to } \\
\text { intermediate }\end{array}$ & Intermediate & Intermediate & $0.10-1.00$ \\
\hline Activated sludge & High & High & . Intermediate & $2.0-10.0$ \\
\hline
\end{tabular}

The $k_{1}$ value is also a function of temperature due to the effect of temperature on the metabolism of the organisms present. In 1889, Arrhenius formulated a general equation for van't Hoff's theory which is often used by microbiologists for pure cultures.

$$
\frac{d\left(\log _{\mathrm{e}} K\right)}{d T}=\frac{u}{R T^{2}}
$$

where

$$
\begin{aligned}
K & =\text { specific reaction rate constant } \\
T & =\text { temperature, }{ }^{\circ} \mathrm{K} \\
R & =\text { universal gas constant } \\
u & =\text { heat of activation. }
\end{aligned}
$$


Theriault ${ }^{25}$ showed an analogy between this equation and the formula normally used to relate $k_{1}$ at different temperatures.

$$
\frac{k_{1} \text { at } T_{1}}{k_{1} \text { at } T_{2}}=\theta^{T}-T_{2}
$$

where

$$
\begin{aligned}
T_{1} \text { and } T_{2} & =\text { two different temperatures } \\
\theta & =\text { thermal constant proportional to } u
\end{aligned}
$$

Many values for $\theta$ have been reported. Streeter and Phelps $^{24}$ found it to be 1.047 , a value still in common use. Pohl ${ }^{18}$ determined the value to be 1.038 working with continuous flow cultures containing an initial broad spectrum of organisms and permitted to reach steady state conditions. A study by Reid ${ }^{21}$ using organisms from the Eielson Lagoon found $k_{1}=0.28$ at $20^{\circ} \mathrm{C}$ and 0.14 at $0.5^{\circ} \mathrm{C}$. The $\theta$ value for this pair of values is also 1.038. Eckenfelder ${ }^{5}$ lists $\theta$ for aerated lagoons as 1.035. Carpenter et al. ${ }^{2}$ working with pulp and paper wastes treated in aerated lagoons determined the average' value for $k_{1}$ to be 0.20 at $20^{\circ} \mathrm{C}$, and $\theta$ for raw and treated effluents to be 1.035 and 1.031 for the 5-day and ultimate BOD respectively.

From the above, it would appear that the probable true value of $k_{1}$ at $20^{\circ} \mathrm{C}$ for domestic wastes is between 0.20 and 0.28 . These values have been used throughout this study along with a value of $\theta=1.038$.

\section{Type of flow}

Two types of flow, or a combination thereof, are normally encountered in a treatment process: plug flow and complete mixing. Plug flow is defined as complete mixing within an initial unit volume of liquid and zero intermixing with adjacent unit volumes as that unit volume travels the length of the container. A unit volume for this study will be defined as one day's flow.' The biota synthesized within a specific unit volume of fluids will tend to remain with that volume of fluid throughout its journey through the lagoon. The curves produced for BOD removal, new cellular material synthesized, and oxygen required will tend to look like those in Figures 2,3 and 4. They will be shortened or lengthened depending upon temperature and concentration of viable organisms (by common usage assumed equal to the MLVSS).

In a completely mixed system, the concentration of BOD, MLVSS and suspended solids will be uniform throughout the vessel. The effluent concentrations will be the same as those in the container. The system will assume a single point on curves similar to those shown in Figures 2, 3 and 4 and maintain that point. This is called maintaining steady-state conditions.

Reid $^{21}$ has described the introduction of dye into the experimental lagoon at Eielson. The dyestained liquid underwent rapid and almost complete mixing within the first cell which is his term for the area between adjacent tubes. Each cell was completely mixed before the flow moved to the next adjacent cell, where the same thing occurred. Flow thus apparently is true plug flow with complete mixing and zero intermixing. This is the major distinguishing feature of lagoons aerated with tubing as opposed to the completely mixed lagoon aerated with surface type aerators. The relatively long detention times used to date for the tubing type lagoons result in a low solids concentration. This in turn results in relatively low $k_{1}$ values and biological activity approximating that observed in the conventional BOD bottle. Because of the dispersed nature of the growth, the rapid initial absorption and adsorption of organic materials by the flock called biosorption will probably not occur. However, it may be important to recycle from the point of maximum solids concentration to prevent a lag caused by lack of seed organisms. This should be investigated. 


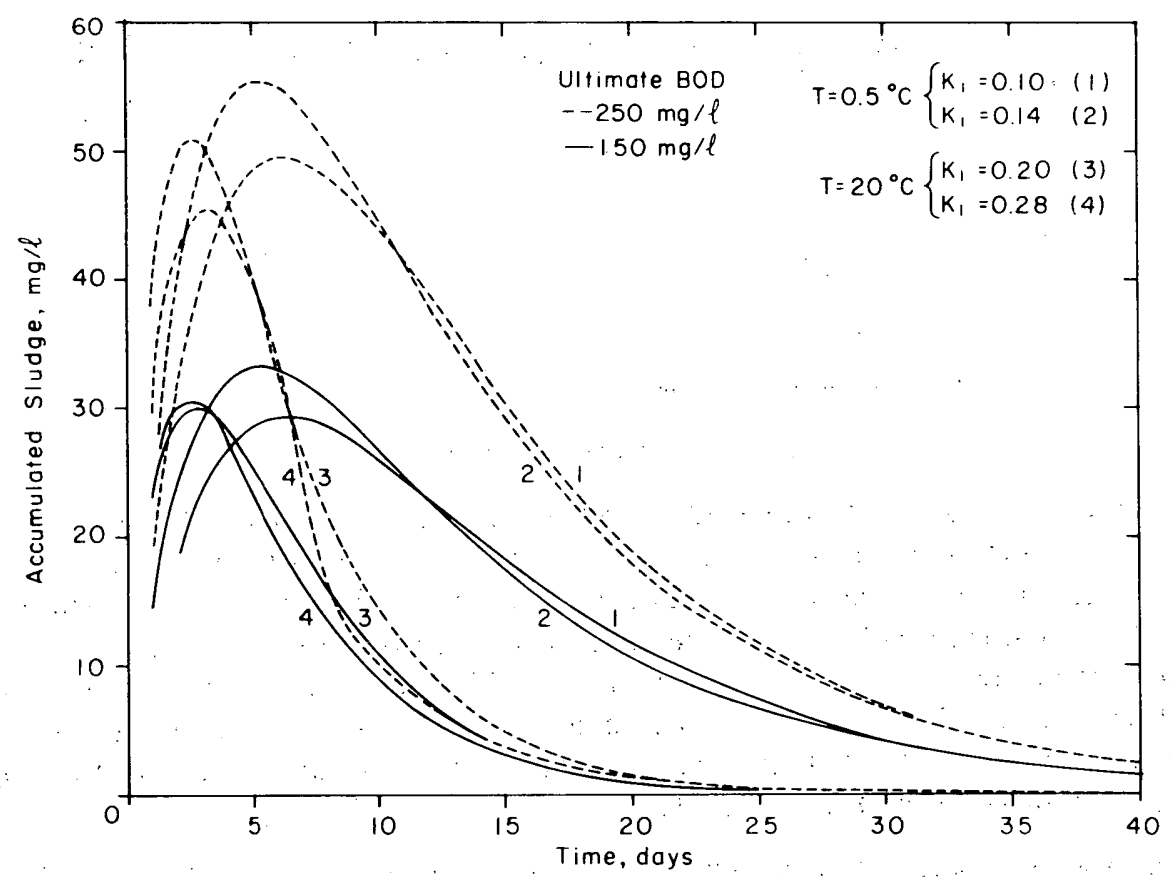

Figure 3. Net accumulated biomass:

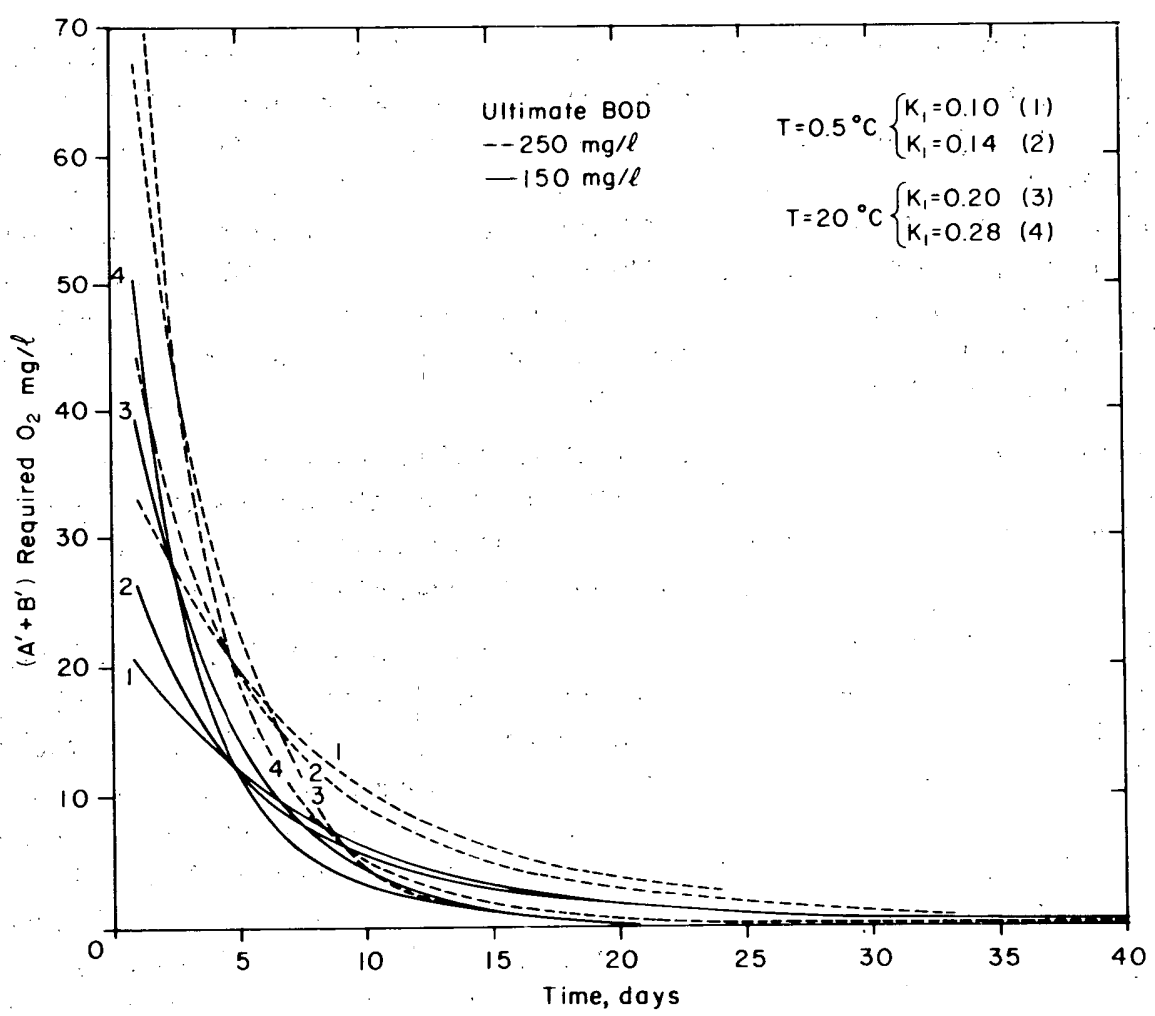

Figure 4. Oxygen required per day. 


\section{Synthesis of new cellular material}

The incoming BOD utilized is first broken down by the organisms into soluble simpler forms which can be taken through the cellular wall. The materials taken into the cells are used as building blocks for the synthesis of new cellular material, repair and maintenance of existing cellular material and for energy. The relationship is expressed by Eckenfelder ${ }^{5}$ as:

$$
\Delta S(\mathrm{lb} / \text { day })=\mathrm{a} L_{\mathrm{r}}(\mathrm{lb} / \text { day BOD removed })-b S_{\mathrm{a}} \text { (lb MLVSS) }
$$

where

$$
\begin{aligned}
\Delta S= & \text { net accumulation of cellular material (which is capable of being subsequently } \\
& \text { degraded biologically) } \\
\mathbf{a}= & \text { the fraction of BOD removed which is synthesized to new cellular material } \\
= & 0.55 \text { for } \mathrm{BOD}_{5} \text { or } \\
= & 0.4 \text { for ultimate BOD (ref. } 5) \\
L_{\mathbf{r}}= & \text { the weight of incoming BOD utilized in unit time } t \\
\mathbf{b}= & \text { the fraction of the total cellular material oxidized per day } \\
= & \text { the mean rate of endogenous respiration } \\
= & 0.2 \text { (ref. } 5 \text { ) } \\
S_{\mathrm{a}}= & \text { the total weight of biologically active solids that is degradable at time } t .
\end{aligned}
$$

The assumption has been made that no intermixing occurs between adjacent unit volumes in the trip through the lagoon. Thus the solids present in any unit volume at any time $t$ will consist of un-utilized incoming materials remaining in suspension, new materials synthesized, and algae. Each will consist of biodegradable and nonbiodegradable fractions. The algae, as described later, will be assumed to exert no oxygen demand until they die in the fall and settle to the anaerobic bottom zone. The inert and nonbiodegradable organic fractions of the incoming and new suspended materials will accumulate in the system. Part of this will settle out and the rest will be discharged with the effluent.

The equation quoted above, as normally used, defines $\Delta S$ as the net accumulation of new cellular material. The first term $\left(a L_{\mathrm{r}}\right)$ represents the weight of new cellular material synthesized in a unit of time. This includes a small nonbiodegradable fraction. ${ }^{5}$ The second term describes the weight of the total biodegradable biomass which is destroyed by auto-oxidation in the same unit of time. $S_{\mathrm{a}}$, then, must be that fraction of the total cellular material present which is biodegradable. However, when set up for computer solution as described below, $S_{\mathrm{a}}$ at time $t$ will equal the $\Sigma \Delta S$ from time $t=0$ to $t-1$ plus $a L_{\mathrm{r}}$ for time $t$, and this includes the nonbiodegradable fraction which accumulated in the system. It becomes necessary, then, to redefine $\Delta S$ as the net accumulation of cellular material which is biologically capable of being subsequently degraded through auto-oxidation. It is recognized that this interpretation will affect the constant a. However, Eckenfelder's value (0.4) was developed under conditions other than those under discussion. It is intended for use until a more accurate value can be determined. The accuracy of the 0.4 value would probably not be improved by refining it to accommodate the exclusion of the nonbiodegradables from the expression.

The net accumulation of cellular material using the foregoing relationships has been programmed for solution by the North Pacific Division Computer Center in Portland, Oregon. It is written in FORTRAN II for the IBM 1920 System which includes a 1620 with $60 \mathrm{k}$ memory, automatic divide, automatic floating point hardware, a 1401 with $4 \mathrm{k}$ memory and expanded print-edit. 


$$
\begin{aligned}
\Delta S=A- & B \\
A= & \text { lb solids synthesized/day } \\
= & 8.33 Q t a L_{\mathbf{r}} \\
= & \text { solids concentration in a unit volume }(\mathrm{mg} / \mathrm{l}) \text { when } Q=M G D, t=1 \text { day } \\
& \text { and } L_{\mathrm{r}}=\mathrm{mg} / 1 \\
= & \mathrm{a} L_{\mathrm{r}} \text { when } Q=\frac{1}{8.33} \text { and } t=1 \\
\mathrm{a}= & 0.4 \text { from ref. } 5 \\
\text { Unit volume }= & 1 \text { day's flow } \\
L_{\mathrm{r}}= & \mathrm{BOD} \text { removed from time } t-1 \text { to time } t(\mathrm{mg} / \mathrm{l}) \\
= & L\left(1-10^{-k}{ }_{1}{ }^{t}\right)-L\left[1-10^{-k}{ }_{1}(t-1)\right] \\
k_{1}= & 0.28 \text { and } 0.20 @ 20^{\circ} \mathrm{C}(\text { two curves }) \\
B= & 1 \mathrm{~b} \text { solids oxidized per day } \\
= & b\left(\sum \Delta S \text { for } t=0 \text { to } t-1+A @ \text { time } t\right) \\
b= & b @ 20^{\circ} \mathrm{C} \theta^{T}-20 \\
= & 0.2 @ 20^{\circ} \mathrm{C} \text { from ref. } 5 \\
\theta= & 1.038 .
\end{aligned}
$$

The computer solutions have been plotted as $\Delta S$ vs time (Fig. 3). The total accumulation of cellular material, including the nondegradable fraction, may be determined from empirical observations (see the section on Suspended solids in effluent).

\section{Oxygen required for synthesis and respiration}

The oxygen required per day for respiration and synthesis of new material (first stage BOD) is:

$$
\left.\mathrm{O}_{2} \text { /day (first stage } \mathrm{BOD}\right)=A^{\prime}+B^{\prime}
$$

where

$$
\begin{aligned}
A^{\prime} & =\mathrm{O}_{2} \text { required for synthesis } \\
& =\frac{\mathrm{a}^{\prime}}{\mathrm{a}} A \\
\mathbf{a}^{\prime} & =1-\mathrm{a} \text { from ref } 5 \\
B^{\prime} & =\mathrm{O}_{2} \text { required for endogenous respiration } \\
& =\frac{b^{\prime}}{b} B \\
b^{\prime} & =1.4 \mathrm{~b} \text { from ref. } 5 .
\end{aligned}
$$

This was added to the computer program and the results plotted (Fig. 4). From this can be determined the required oxygen transfer capability at any point in the lagoon to satisfy the first stage BOD. The cumulative oxygen demand versus time has also been plotted (Fig. 5). From this can be determined the total oxygen required. 


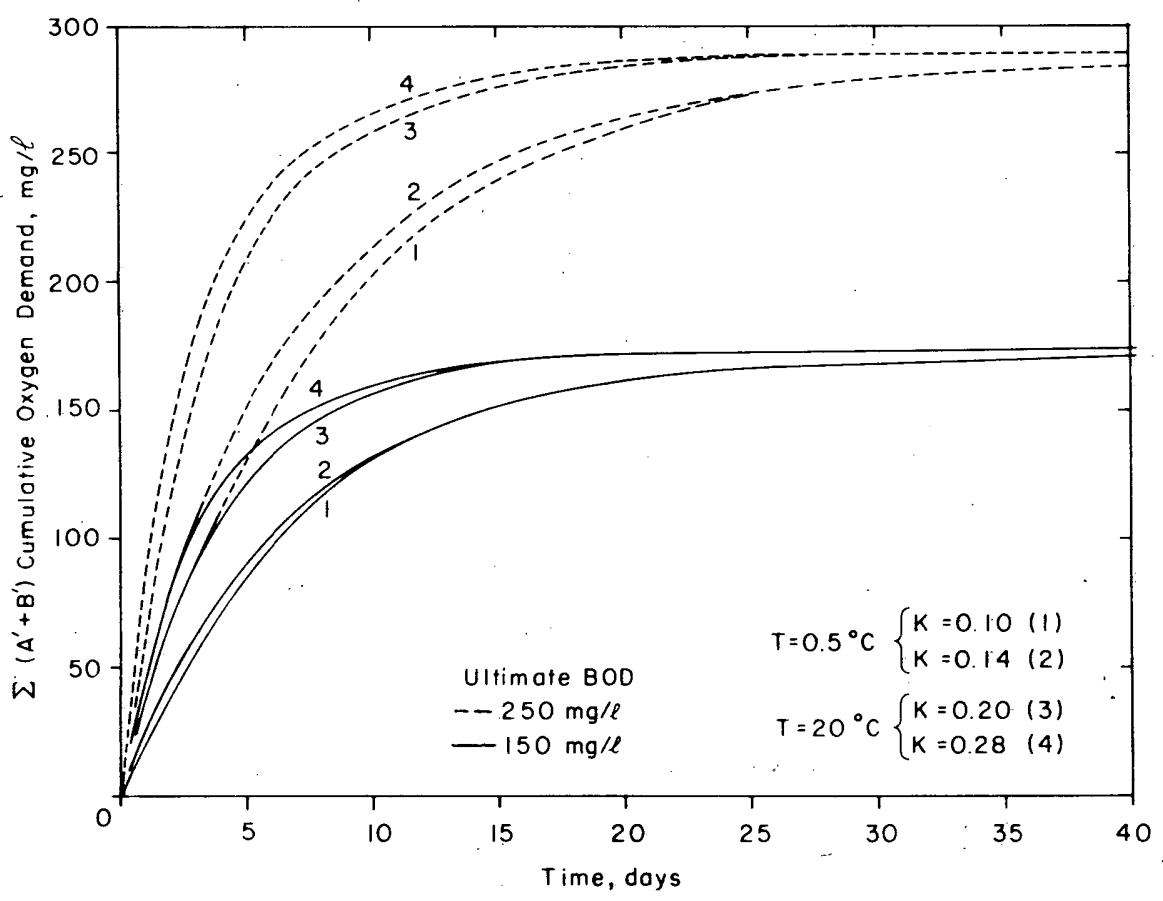

Figure 5. Cumulative oxygen demand.

The second stage BOD will not be considered for this study. The critical oxygen demands (and consequently oxygen transfer capabilities) can be expected to occur in the inlet end of the pond (see Fig. 4). This is well before the onset of the second stage BOD. There is also some doubt whether nitrification occurs at all when the pond is functioning at low winter temperatures. In the summer, algae may be expected to utilize ammonia as rapidly as it is produced. Reid ${ }^{22}$ lists nitrates in the Northway lagoon as varying from 0 to $0.26 \mathrm{mg} / 1$ in the influent and from 0 to 0.32 in the effluent. The mean was 0.15 in the influent and 0.07 in the effluent. The Northway lagoon, because of probable lack of short circuiting as will be described later, is considered to be the only one of the three lagoons described to have significance.

\section{Oxygen required by benthal layer}

Accumulated organics in the anaerobic zone are decomposed to organic acids. These, in the presence of permissible $\mathrm{pH}$ and temperature, are converted to methane, $\mathrm{CO}_{2}, \mathrm{H}_{2}, \mathrm{~N}_{2}$ and other gases. According to Oswald ${ }^{15}$ methane fermentation decreases sharply below $12^{\circ} \mathrm{C}$ and is almost nonexistent ${ }^{*}$ below $4{ }^{\circ} \mathrm{C}$. A tabulation of observed gas production from a facultative pond is given by Oswald. ${ }^{15}$

Oswald reports that gas emission is virtually nonexistent below $4^{\circ} \mathrm{C}$. This may be partially due to the increased solubility of methane and nitrogen at low temperatures. The acid formers have been observed to be slightly more active at low temperatures than the methane formers. The anaerobic zone thus functions as an unheated digester which serves as a refrigerated storehouse during winter months. Table III shows the effect of temperature on the ability of the anaerobic zone to function. The theoretical quantity of gas is a constant and is independent of temperature. It varies from 8 to $12 \mathrm{ft}^{3} / \mathrm{lb}$ BOD stabilized. ${ }^{15}$ Assuming an average value of $10 \mathrm{ft}^{3} / \mathrm{lb}$, Table III predicts a net increase in undigested sludge will occur when the liquid temperature is below $19^{\circ} \mathrm{C}$. Materials in the benthal layer will thus accumulate during the winter and be utilized during the summer. Anaerobic digestion will exert a BOD load on the zone immediately above. The demand results from oxidation of anaerobic products which diffuse up through the sludge into the aerobic zone above. Camp ${ }^{1}$ quotes studies by Fair et al., which measured the oxygen demand of sludge layers of various thicknesses at $20^{\circ}$ to $25^{\circ} \mathrm{C}$. 
Table III. Gas production in a facultative pond at a point where the benthic BOD load is $200 \mathrm{lb} /$ acre day. (From Oswald. ${ }^{15}$ )

\begin{tabular}{ccc}
\multirow{2}{*}{$\begin{array}{c}\text { Temp } \\
\left({ }^{\circ} \mathrm{C}\right)\end{array}$} & \multicolumn{2}{c}{ Gas collected } \\
\cline { 2 - 3 } $\mathrm{ft} \mathrm{t}^{3} / \mathrm{acre}$ day & $f t^{3} / \mathrm{lb} B O D^{*}$ \\
\hline 0 & 0 & 0 \\
4 & 40 & 0.2 \\
8 & 160 & 0.8 \\
12 & 600 & 3.0 \\
16 & 1300 & 6.5 \\
20 & 3150 & 15.7 \\
22 & 4900 & 24.5 \\
\hline
\end{tabular}

*Destruction of $1 \mathrm{lb}$ BOD normally liberates $8-10 \mathrm{ft}^{3}$ gas.

Table IV. $\mathrm{O}_{2}$ demand of bottom deposits. (From Camp. ${ }^{1}$ )

\begin{tabular}{ccccc}
$\begin{array}{c}\text { Mean } \\
\text { depth } \\
(\mathrm{cm})\end{array}$ & $\begin{array}{c}\text { Initial vol } \\
\text { solids } \\
\left(\mathrm{kg} / \mathrm{m}^{2}\right)\end{array}$ & $\begin{array}{c}L_{\text {do }} \\
\left(\mathrm{g} / \mathrm{m}^{2}\right)\end{array}$ & $\begin{array}{c}\text { Initial demand } \\
\left(\mathrm{g} / \mathrm{m}^{2} \text { day }\right)\end{array}$ & $k_{4}$ \\
\hline 10.2 & 3.77 & 739 & 4.65 & \\
4.75 & 1.38 & 426 & 3.09 & 0.0027 \\
2.55 & 0.513 & 227 & 1.70 & 0.0031 \\
1.42 & 0.188 & 142 & 1.08 & 0.0032 \\
1.42 & 0.188 & 134 & 1.02 & 0.0033 \\
\hline
\end{tabular}

The relationship is given by

$$
L_{\mathrm{d}}=L_{\mathrm{do}} 10^{-k} 4^{t}
$$

where

$$
\begin{aligned}
L_{\mathrm{d}} & =\text { total areal BOD of bottom deposits in } \mathrm{g} / \mathrm{m}^{2} \text { after time } t \\
L_{\mathrm{do}} & =\text { initial value of } L_{\mathrm{d}} \\
k_{\mathbf{4}} & =\text { areal demand rate constant. }
\end{aligned}
$$

The values above are for temperatures from $20^{\circ}$ to $25^{\circ} \mathrm{C}$. Table III can be used to relate these values to other temperatures when necessary. However, normal design in Alaska will compare summer temperatures (values given) and winter temperatures (no benthal load) with no need to interpolate. Also Table IV assumes an initial deposit with subsequent fermentation. In the subject lagoons, material will be deposited continuously with a buildup in the winter and reduction during the summer. Thus, $L_{\mathrm{do}}$ is the value of interest. Camp makes the assumption that the oxygen demand is uniformly exerted on the overlying waters. Then fur a mean sludge depth of $2.55 \mathrm{~cm}$ and a liquid depth of $1 \mathrm{~m}$, the oxygen demand would be $227 \mathrm{mg} / \mathrm{l}$. Consideration of the equation given above will show that long periods of time are required to reduce the oxygen demand materially. For example, for $k_{4}=0.0032$, almost 100 days are required to reduce the demand by $50 \%$. 
It should be noted that the promotion of methane fermentation is highly desirable for BOD removal. Under ideal conditions, several hundred pounds of organic matter per acre day may be converted to methane. ${ }^{16}$ It is also believed that methane fermentation blocks the occurrence of sulfate reduction primarily because it controls the buildup of organic matter which is an essential for sulfate reduction. Acid fermentation without methane fermentation is undesirable, particularly in waters with a high sulfate content. This produces a condition analogous to a "stuck" digester with attendant odors if the gases are not completely oxidized in their passage through the aerobic zone. The increased production of hydrogen sulfide also obviously increases the oxygen demand on the overlying waters. Acid decomposition is more likely to be a problem in climates where summer liquid temperatures become very warm $^{16}$ - not a likely occurrence in Alaskan climates. Also, algae tend to raise the $\mathrm{pH}$ in the medium, preventing acid inhibition of the methane formers.

Another possibility for the digestion of bottom sludge has been reported by Reid. ${ }^{21}$ Sludge deposited around the inlet to the Eielson lagoon underwent resuspension by physical means the following spring. This may have been caused by nitrate reduction with nitrogen gas carrying the sludge to the surface. The floating sludge was then broken up by turbulence and apparently decomposed aerobically.

Murphy ${ }^{12}$ has suggested the possible desirability of bi-level lagoons in which the aeration tubing would be suspended at mid-depth and the lagoon depth would exceed $10 \mathrm{ft}$, preferably approaching $20 \mathrm{ft}$. This would provide a quiescent, oxygen-free lower level for anaerobic digestion. Oswald $^{16}$ also suggests the desirability of designing facultative ponds in a way that produces bottom conditions favorable to methane fermentation. Such ponds appear to hold promise in Alaska for at least two reasons. The first is the relatively high efficiency which could be expected, with consequent low initial costs. Second, the shape would provide maximum protection from the elements and result in warmer liquid temperatures. Turnover caused by warming or cooling to $4^{\circ} \mathrm{C}$ could be expected twice a year. This could create a problem if not confined to the anaerobic levels.

The accumulation of digested sludge has not been determined accurately, but apparently is not great. Oswald ${ }^{16}$ says sludge accumulation in quiescent facultative lagoons at Concord, California, amounted to 1 to $2 \mathrm{ft}^{3}$ per annum per capita. Carryover of inert materials in lagoons using tubing for aeration should result in less accumulation on the floor of the pond than for facultative lagoons.

\section{Influence of algae on effluent}

If algae are discharged into the receiving body the effect can be predicted as follows:

1. If postchlorination is practiced to reduce coliform count, most of the algae may be expected to be dead. The stoichiometric relationship is given by Oswald as:

$$
\mathrm{C}_{11} \mathrm{H}_{29} \mathrm{O}_{7} \mathrm{~N}+14 \mathrm{O}_{2}+\mathrm{H}^{+} \rightarrow 11 \mathrm{CO}_{2}+13 \mathrm{H}_{2} \mathrm{O}+\mathrm{NH}_{4}^{+}
$$

The weight of oxygen required to oxidize the dead algal material therefore is 1.56 times the weight of material oxidized. Thus the BOD $=1.56 C_{c}$, where $C_{c}=$ algal concentration.

2. If the algal cells are discharged alive into the receiving body and the receiving body has a nutrient level too low for them to grow, the cells will vegetate as long as they have access to carbon dioxide from the atmosphere and sunlight: If they vegetate, they will have a small but measurable continuous oxygen demand. Oswald and Gotaas ${ }^{17}$ predict this as being about $1 / 10$ of the ash-free dry weight of the cells per day at $25^{\circ} \mathrm{C}$. This value would be temperature-dependent and would decrease to almost zero at $0^{\circ} \mathrm{C}$. Algal concentrations from 200 to $300 \mathrm{mg} / 1$ are reported to have been held for 3 months without putrefaction. 
3. If the receiving body contains an adequate nutrient load, the cells will grow and produce oxygen. However, the inorganic ammonia, nitrates, and phosphates (termed nutrients) which result from aerobic digestion, when introduced to a receiving body, encourage eutrophication. This is an aging process which results in a high level of rooted and aquatic plant life, and can result in nuisance conditions. Algae in the treatment process, provided they can be excluded from the effluent, will strip nutrients and thus reduce the concentration introduced into the receiving body. The removal of nutrients is normally termed tertiary treatment and is the next step up the ladder above secondary treatment.

\section{Influence of algae within the lagoon}

As described above, algae will strip nutrients from the process if they can be excluded from the effluent. This, however, will result in an accumulation of algae which must in turn undergo treatment. The excess algae may be expected to remain at the surface, gradually increasing in concentration until they reach the vegetating stage. This assumes that velocities through the lagoon are such that algae'synthesized are carried to the outlet end of the lagoon where the nutrient load is much lower than at the inlet end where they were synthesized. If this is not true, excess growth will not occur. Concentrations of 200 to $300 \mathrm{mg} / 1$ can be expected to survive for three months without putrefaction as long as light and access to atmospheric carbon dioxide are afforded. Ultimately, however, the cells will settle to the bottom. Oswald and Gotaas ${ }^{17}$ report that algae in the dark will remain alive for a length of time which is principally a function of temperature. Algal cells will survive in the dark for up to two weeks at temperatures near freezing, but will die and be decomposed in a few days in the dark at temperatures above $25^{\circ} \mathrm{C}$. From this it may be deduced that algal concentrations may be expected to increase until nutrients become limiting. At that point, they should remain at the surface in a vegetating stage until fall, when ice cover would exclude atmospheric carbon dioxide and oxygen and cause them to die and settle to the bottom. At the cold winter temperatures they would be held in storage in the anaerobic zone to be decomposed in the spring.

\section{Method for excluding algae from the effluent}

At retention times less than 14 days, algae in the effluent has not proven to be a problem. The normal design provides a quiescent area in the vicinity of the outlet structure. Since photosynthesis is basic to the life cycle of algae, the algal concentration approaches zero when the available light is zero. Location of the drawoff point below the depth of zero light penetration therefore should eliminate algae.

Oswald and Gotaas ${ }^{17}$ report that a suspension of algal cells absorbs light within close limits in accordance with the Beer-Lambert relationship:

$$
d=\frac{\log _{\mathrm{e}} I_{\mathrm{i}}}{C_{\mathrm{e}} a}
$$

where

$$
\begin{aligned}
d & =\text { depth at which light intensity equals zero } \\
I_{\mathrm{i}} & =\text { incident light intensity } \\
C_{\mathrm{c}} & =\text { algal concentration at the surface }(\mathrm{mg} / \mathrm{l}) \\
a & =\text { specific absorption coefficient (normally } 1.5 \times 10^{-3} \text { for sewage-grown algae) }
\end{aligned}
$$




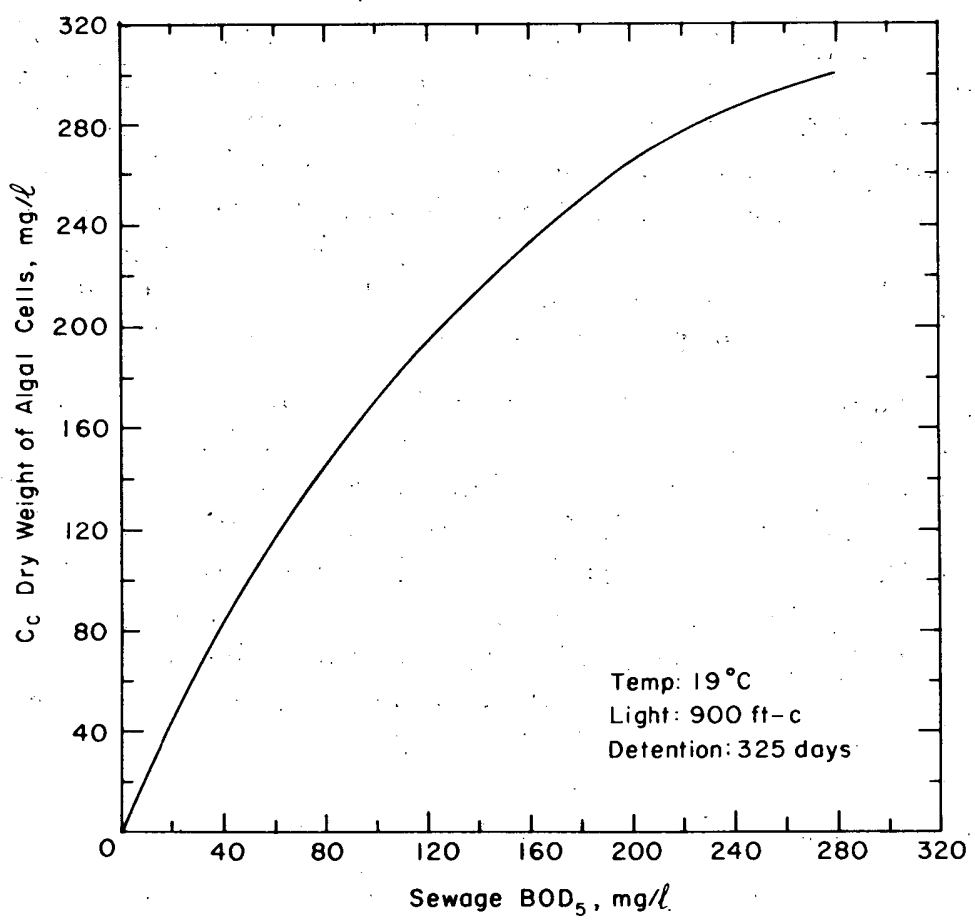

Figure 6. Effect of $B O D$ on the concentration of algal cells in continuous cultures. (From Oswald and Gotaas. ${ }^{17}$ )

The concentration of algae at any point in the lagoon can be expected to be determined by the concentration of nutrients available to the algae. Assuming the nutrients are taken up by the algae as rapidly as they are produced, it should be possible to determine the algal concentration at any point in the lagoon from the stoichiometric relationships. However, in actual practice, implementation of the preceding statement is difficult. The actual algal concentration will depend upon which of the nutrients becomes limiting first. Oswald and Gotaas ${ }^{17}$ report that a useful rule for the relationship between nitrogen and growing algae is:

$$
C_{\mathrm{c}}=10 \mathrm{~N}
$$

where

$$
\begin{aligned}
C_{\mathrm{c}} & =\text { maximum algal concentration }(\mathrm{mg} / \mathrm{l}) \\
N & =\text { nitrogen concentration }(\mathrm{mg} / \mathrm{l}) .
\end{aligned}
$$

The constant 10 stems from the assumption that $80 \%$ of the nitrogen in the waste is recovered and that algal cells are $8 \%$ nitrogen.

Phosphorus rarely becomes limiting because it normally does not exceed $1 \frac{1}{2} \%$ of the dry weight of algae. Increased use of detergents makes it unlikely that either phosphorus or nitrogen will be limiting.

Both magnesium and potassium are also essential to algal growth. However, since algae cells normally contain approximately $0.5 \%$ potassium and $1 \%$ magnesium, and since domestic wastes normally contain more than $5 \mathrm{mg} / \mathrm{l}$ of both of these elements, they normally will not be limiting. 
Carbon is the limiting element based on the stoichiometric relationships between biological oxidation and algal synthesis. However, appreciable amounts of carbon dioxide can also be absorbed from the atmosphere at the surface. Active photosynthesis can be expected to increase $\mathrm{pH}$ which increases the solubility of carbon dioxide in water. Under these conditions the carbon dioxide appears in solution as the bicarbonate ion and becomes available to the algae at once. Additional research will be necessary to determine which nutrient will become limiting first. In the interim period a graph prepared by Oswald and Gotaas ${ }^{17}$ may be used to estimate the concentration of algal cells which may be expected at different waste concentrations (Fig. 6).

Clark $^{3}$ has pointed out the potential influence of seasonal overturning on the efficiency of this method for excluding algae. For the method to be effective a quiescent area must be provided. The required tubing spacing to permit algae to remain at the surface must be determined by actual observation. Reid ${ }^{21}$ has observed no evidence of overturning with $20-\mathrm{ft}$ spacing. He refers to the system described by Ogborn ${ }^{13}$ which is used to prevent thermal stratification in freshwater reservoirs at Johnstown, Pennsylvania. Three runs of tubing $400 \mathrm{ft}$ long distributing $22 \mathrm{ft}^{3} / \mathrm{min}$ air are sufficient to obtain complete mixing in the 75-million-gallon Laurel Run Reservoir. This would indicate that overturning should not be a problem. No evidence of overturning has been observed in the seven functioning lagoons built by the Alaska District to date.

\section{Suspended solids in effluent}

The synthesis of new cellular material and subsequent autodigestion have been described under Synthesis of new cellular material. The mathematical expression defining the net concentration of cellular material after any elapsed time $t$ has been programmed for computer solution and the results plotted (Fig. 3).

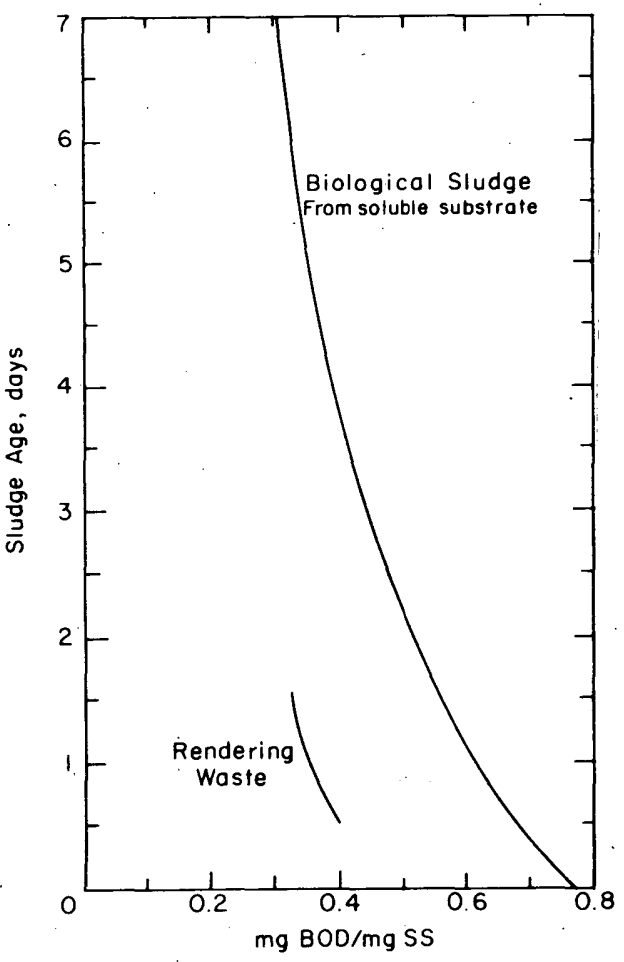

Figure 7. BOD characteristics of biological sludges. (From Eckenfelder. ${ }^{5}$ )
The assumption was made that endogenous respiration is a first order reaction, in which the rate of oxidation of the cellular material would be a constant percentage of the material remaining. Since the various constituents of the biomass vary in the ease with which they can be oxidized this assumption is not strictly valid. However, pending actual determination of the change in $b$ with time, the value used has been found to be reasonably accurate by Eckenfelder. ${ }^{5}$ The $\Delta S$ as defined for this study will be a measure of the remaining biodegradable material. The actual total weight of suspended solids, excluding algae, may be determined from work reported by Eckenfelder. Eckenfelder ${ }^{5}$ has plotted mg BOD/mg SS vs sludge age for a sludge developed from a soluble waste, and from a rendering waste which included a significant quantity of nondegradable materials (see Fig. 7). It is believed that the increasingly wide tubing spacing near the outlet end of the lagoon will permit the settling out of most of the inert materials in the domestic waste under discussion. Therefore, the curve developed from the soluble substrate in Figure 7 should more accurately describe the effluent from the lagoon. The curve becomes asymptotic to a value of 0.3 as the sludge age exceeds 7 days. Then: 
SS at time $t=\frac{\sum \Delta S \text { at time } t}{m}$

where

$$
\begin{aligned}
S S & =\text { suspended solids, mg/1 } \\
\Delta S & =\text { previously defined } \\
m & =\text { value from Figure } 7 .
\end{aligned}
$$

The sludge age $G$ may be determined from the relationship

$$
G=\frac{\Sigma \Delta S}{\Delta S}
$$

\section{Reduction in coliform organisms}

Numerous authors have reported impressive reductions in coliform organisms in conventional facultative lagoons. Oswald ${ }^{15}$ reports on coliform die-away observed in an experimental facultative pond at Richmond, California (Fig. 8). He also describes a relationship recently published by Marais and Shaw in which a rational method is presented for mathematical prediction for coliform removal. However, the method does not include a correction for temperature, and was shown by Oswald to be incorrect at temperatures other than those used by Marais and Shaw. Oswald and Gotaas $^{17}$ state that in laboratory and pilot plant tests they were able to observe no reduction in coliform organisms other than the normal die-away, except in certain light-saturated cultures. These were affected by the known germicidal effect of natural sunlight.

Camp $^{1}$ describes the rate of decrease in coliform count in natural waters as being mathematically

$$
\frac{N_{\mathrm{T}}}{N_{0}}=10^{-K_{\mathrm{b}} t}
$$

where

$$
\begin{aligned}
& N_{\mathrm{T}}=\text { count after time } t \text {, days } \\
& N_{0}=\text { initial count } \\
& K_{\mathrm{b}}=\text { bacterial decrease rate constant (see Fig. 9). }
\end{aligned}
$$

\section{Depth}

Lagoons which depend on algae and surface reaeration for oxygen obtain their oxygen supply at the surface. Thus the ratio of surface area to total volume becomes critical and depths are limited to 3 to $5 \mathrm{ft}$ for facultative lagoons and $1 \mathrm{ft}$ or less for high rate aerobic ponds. Tubing is the prime source of oxygen for the lagoons discussed herein. Oxygen transfer is accomplished at the bubble air / water interface. The efficiency is a function of bubble size and duration of contact at any given temperature and initial oxygen concentration. Thus, an increase in depth will increase the oxygen transfer efficiency because it increases the duration of contact at the interface. Increase in depth has several other advantages. Less land is required for a given detention time. Less surface area is offered for the growth of algae if algae must be excluded from the receiving body. Finally, reduction in surface area will result in less heat loss at the surface. 


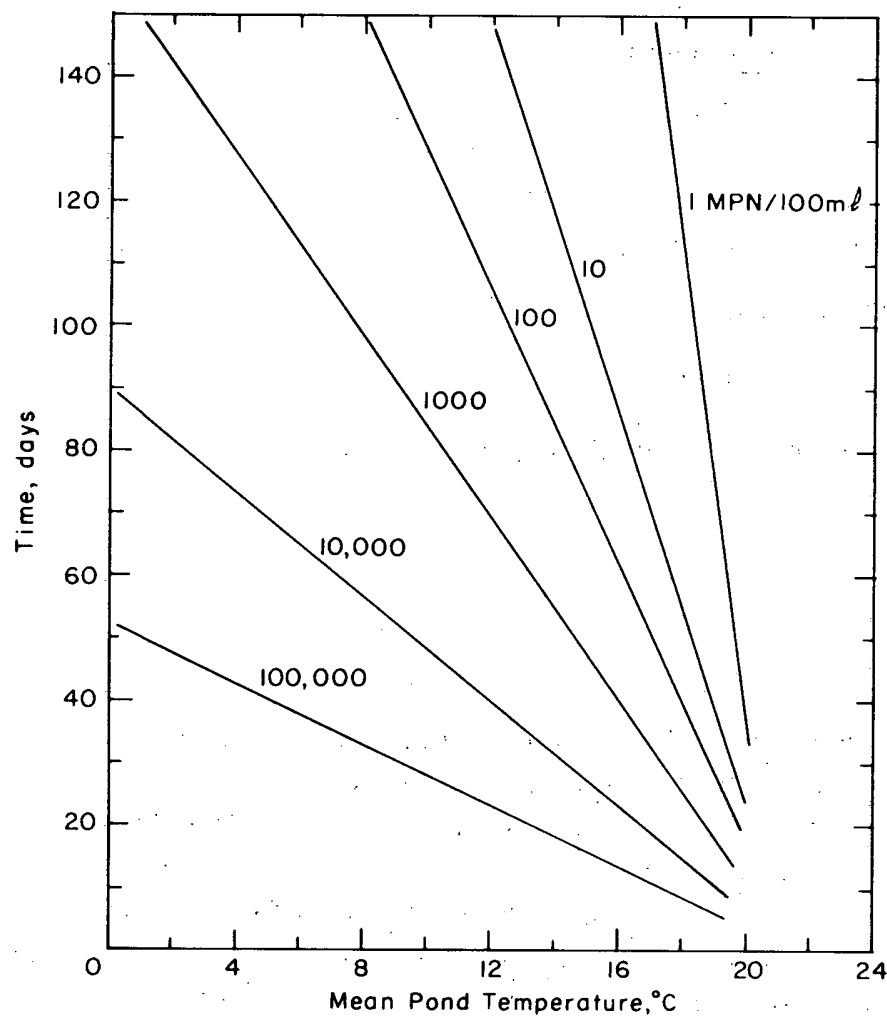

Figure 8. Observed MPN $/ 100 \mathrm{ml}$ in a single falcultative pond as a function of time and temperature. Initial MPN $10^{8} / \mathrm{ml}$. (From Oswald. ${ }^{15}$ )

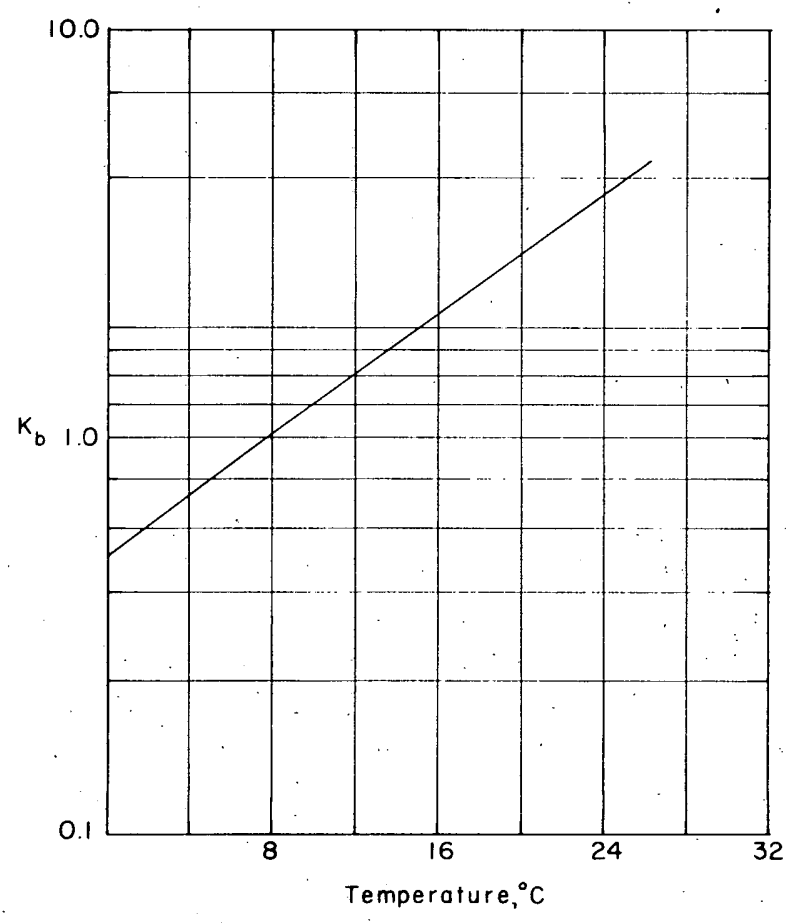

Figure 9. Effect of water temperature on values of $\mathrm{K}_{\mathrm{b}}$ for death rate of coliform organisms. (From Camp. ${ }^{1}$ ) 
The decreased metabolic rates, shown graphically in Figures 2 and 3, will normally make the winter detention time critical for sizing the lagoon. The volume expected to be occupied by ice should be deducted from the total volume available when computing detention time. The depth selected will depend upon the character of the site selected, location of groundwater and nature of the material. 'Depths exceeding $10 \mathrm{ft}$ probably will require multistage blowers. The blower selected must be capable of producing oil-free air.

\section{Oxygen sources}

The demand for oxygen at any point in the lagoon will be the demand for synthesis and respiration (Fig. 4) plus that exerted by the benthal layer. During the summer, it must be satisfied by the tubing, surface reaeration and algae. Winter ice cover will reduce these sources to the tubing. Algae can be expected to supply up to $50 \mathrm{lb} /$ acre day under ideal summer conditions. ${ }^{16}$

Extensive work has been reported by Dobbins and others on the rate of absorption of oxygen from the atmosphere at the surface (normally termed surface renewal). The parameters are a function of temperature, turbulence, percentage saturation at the surface, wind velocity and liquid depth. Camp ${ }^{1}$ presents an empirical method for evaluating these parameters. Oswald ${ }^{16}$ reports that less than $40 \mathrm{lb}$ oxygen/acre day may be introduced into a quiescent lagoon even under anaerobic conditions. The presence of algae at the surface can easily produce saturated conditions which will effectively prevent oxygen transfer. Therefore it probably is best to ignore this source of oxygen as a design parameter pending further evaluation.

An evaluation of oxygen transfer by the tubing would normally be accomplished using the twofilm theory which assumes liquid and gas films at the interface which constitute the barriers to oxygen transfer. Using Fick's law it can be shown that

$$
\frac{d m}{d t}=K_{\mathrm{L}} A\left(C_{\mathrm{s}}-\mathrm{C}\right)
$$

where

$$
\begin{aligned}
\frac{d m}{d t} & =\text { time rate of mass transfer by diffusion } \\
K_{\mathrm{L}} & =\text { liquid film coefficient } \\
A & =\text { total cross-sectional area through which diffusion occurs } \\
\mathrm{C}_{\mathrm{s}} & =\text { oxygen saturation concentration } \\
\mathrm{C} & =\text { oxygen concentation in the medium } \\
\text { or } \quad C_{\mathrm{S}}-\mathrm{C} & =\text { dissolved oxygen deficit } \\
& =\text { concentration gradient. }
\end{aligned}
$$

The form most often used is

$$
\frac{d c}{d t}=K_{L} a\left(C_{s}-C\right)
$$

where

$$
\begin{aligned}
a & =\text { ratio of interfacial area to liquid volume } \\
K_{\mathrm{L}} \mathrm{a} & =\text { overall mass transfer coefficient. }
\end{aligned}
$$


Eckenfelder ${ }^{4}$ has shown that for bubble aeration, oxygen transfer characteristics can be correlated according to the Sherwood, Reynolds and Schmidt numbers.

Oxygen transfer efficiencies have been determined for the tubing by an industrial laboratory under a contract with the manufacturers of the tubing. The oxygen transfer efficiencies were reported for different depths of distilled water at $20^{\circ} \mathrm{C}$ for tubing delivering 1 and $2 \mathrm{ft}^{3} / \mathrm{min}$ of air per $100 \mathrm{ft}$ of tubing.

The percent efficiency $=\frac{\text { wt } \mathrm{O}_{2} \text { absorbed/unit time }}{\text { wt } \mathrm{O}_{2} \text { supplied/unit time }} \times 100$.

These efficiencies were determined using distilled water. The $K_{\mathrm{L}}$ a for a waste will be influenced by the materials dissolved and in suspension, and will differ from that for distilled water. The relationship is given by Thimsen ${ }^{26}$ as

$$
\frac{K_{\mathrm{L}} \mathrm{a} \text { (waste) }}{K_{\mathrm{L}} \mathrm{a} \text { (water) }}=\alpha .
$$

He reports $a$ as varying from 0.5 to 1.0 depending upon the type of waste and the method of aeration. This value should be determined by investigation. In the interim, it is suggested that the low value $(0.5)$ be used.

It should be noted that biological activity will be aerobic if the dissolved oxygen concentration exceeds $0.5 \mathrm{mg} / \mathrm{l}$. Higher dissolved oxygen concentrations may be useful to supplement the supply of oxygen in the receiving body. The nature of the receiving body will determine the value of designing for a high concentration in the effluent. Until the design parameters described herein are more accurately evaluated, it may be dangerous to design for a value of less than $50 \%$ of saturation.

\section{Analysis of existing systems}

It is difficult to compare the results predicted by this study with those reported for existing lagoons for several reasons:

1. Short circuiting could radically affect the results reported. The extent of short circuiting cannot be determined for any of the lagoons reported upon. The Northway lagoon was built with vertical sides and short circuiting would be expected to be negligible if the tubing was extended to the walls. It is not clear if this was done. The consistency of results, however, is significantly superior to the Bethel and Eielson lagoons.

2. The extent to which the reported effluent quality is affected by algae has an effect. Both the BOD and suspended solids would be increased if algae were present. The Northway lagoon, although built with vertical walls, was designed to draw the effluent from a point approximately two feet below the surface. ${ }^{21}$

3. Each set of values was the result of a detention time which either could not be determined or was not clear in many cases. Flow rates often fluctuated widely, evidently as a result of combined sewers or extensive infiltration into the sewer system. The McKinney study, ${ }^{10}$ for example, was accomplished without flow rates because "political procrastination prevented obtaining a flow measuring device" during the study.

4. Most of the existing lagoons which use tubing as the source of oxygen were originally designed as facultative lagoons. Shallow depths and irregular bottoms could produce nonuniform flow patterns. 
For these reasons, analyses of results reported from existing installations shed little light on the validity of the analysis presented herein.

\section{Summary}

A rational approach to the design of aerated lagoons using tubing as the source of oxygen has been presented. The various parameters have been identified and an evaluation of each attempted based upon present knowledge. An attempt has also been made to identify areas where additional research is needed to accurately evaluate the parameters.

A typical design should evolve in three stages. Each stage should be evaluated for winter and summer operation.

1. The first stage should be a joint evaluation of the receiving body with the agency responsible for protection of the quality of the receiving body to determine the required effluent quality. For domestic wastes emanating from a military installation, this would normally be a determination of allowable BOD, suspended solids and coliform organism count in the effluent.

2. The second stage would be the determination of the required detention time to accomplish the objectives developed in stage 1. Effluent BOD will be a combination of the items described under the sections on Aerobic digestion, Synthesis of new cellular material and Influence of algae on effluent. The effluent-suspended solids can be determined from the section Suspended solids in effluent, and the coliform count from the section Reduction in coliform organisms.

3. The last stage would be an evaluation of the oxygen demand within the lagoon to determine tubing quantity and spacing and total air requirements. Total oxygen requirements would be the sum of the sections on Oxygen required for synthesis and respiration (Fig. 5) and Oxygen required by benthal layer. The distribution of the oxygen transfer equipment can be determined from the same two sections and from Figure 4.

The constants used for actual design should be the conservative values until they can be more accurately defined. The resulting design should be conservative. It is anticipated that research findings will modify and more sharply define this design approach with resulting increased treatment plant efficiency.

\section{BIBLIOGRAPHY}

1. Camp, T.R. (1963) Water and its impurities. New York: Reinhold Publishing Corp.

2. Carpenter, W.L., Vamvakias, J.G. and Gellman, I. (1966) Temperature relationships in aerobic treatment and disposal of pulp and paper wastes. Johns Hopkins University, Baltimore, Md., Paper prepared for the National Council for Stream Improvement.

3. Clark, S. (1967) FWPCA, Alaska Water Lab, Fairbanks, Personal Communications.

4. Eckenfelder, W.W., Jr. (1959) Factors affecting the aeration efficiency of sewage and industrial wastes. In Sewage and Industrial Wastes, vol. 31, no. 1, p. 61.

5.

(1967) An integration of biological waste treatment design. University of Texas, Presented to the ASCE Environmental Engineering Conference, Dallas, Texas.

6. and O'Connor, D.J. (1960) Treatment of organic wastes in aerated lagoons. New York State Water Pollution Control Board Research Report no. 7 .

7. Higgins, P.M. (1965) Problems and new developments in the lagooning of wastes. The Metropolitan Corporation of Greater Winnipeg, Presented to the Canadian Institute of Public Heal th Inspectors, Winnipeg, Manitoba. 


\section{BIBLIOGRAPHY (Cont'd)}

8. Hoover, et al. (1953) An interpretation of the BOD test in terms of endogenous respiration of bacteria. In Sewage and Industrial Wastes, vol. 25, no. 10, p. 1163.

9. Hurwitz, E. (1963) Conversion to an aerated lagoon extends pond's life. In Water and Sewage Works, vol. 110, p. 359.

10. McKinney, R.E. (1966) Two case studies of overloaded oxidation ponds. University of Kansas.

11. Meyer, O.L. (1962) Aeration systems increase lagoon capacity-add operating flexibility. In Public Works, vol. 93, p. 8.

12. Murphy, R.S. (1967) University of Alaska, Personal Communications.

13. Ogbom, C.M. (1966) Aeration system keeps water tasting fresh. In Public Works, April.

14. Orford, H.E. and Ingram, W. T. (1953) Deoxygenation of sewage: I. Critical review of the monomolecular formula. In Sewage and Industrial Wastes, vol. 25, no. 4, p. 419.

15. Oswald, W.J. ( ) Advances in stabilization pond design. University of Califomia.

16. (1960) Stabilization pond research and installation experiences in California. University of California, Waste Stabilization Lagoons Symposium, Kansas City, Mo., Public Heal th Service Publication no. 872.

17. and Gotaas, H.B. (1957) Photosynthesis in sewage treatment. In Transactions American Society of Civil Engineers, vol. 122, p. 73-105.

18. Pohl, E.F. (1967) The effect of low temperatures on aerobic waste treatment processes. M.S. Thesis, University of Washington.

19. Reid, L.C., Jr. (1965) The aerated sewage lagoon in Arctic Alaska. Arctic Heal th Research Center, Presented to the 17 th Annual Convention of the Western Canada Water and Sewage Conference, Edmonton, Alberta.

20. (1966) The operation of an aerated waste stabilization pond in central Alaska. In Water and Sewage Works, August.

21. (1967) Arctic Health Research Center, Personal Communications.

22. and Benson, B.E. (1966) Observations on aerated sewage lagoons in Arctic Alaska. Arctic Heal th Research Center, Presented to the 18th. Annual Convention of the Westem Canada Water and Sewage Conference, Regina, Sa skatchewan.

23. Sellner, E.P. (1966) Air-aqua aerated lagoons. Presented to the 38th Annual Conference of the Arizona Water and Pollution Control Association, Tucson, Arizona.

24. Streeter, H.W. and Phelps, E.B. (1925) A study of the pollution and natural purification of the Ohio River. U.S. Public Heal th Service Bulletin no. 146.

25. Theriault, E.J. (1927) The oxygen demand of polluted waters. U.S. Public Health Service Bulletin no. 173.

26. Thimsen, D.J. (1965) Biological treatment in aerated lagoons. Minnesota Dept. of Heal th, Presented at the Twelf th Annual Waste Engineering Conference, University of Minnesota.

27. Tillbury, G. (1967) Anchorage Office, Federal Aviation Agency, Personal Communications. 
DOCUMENT CONTROL DATA - R \& D

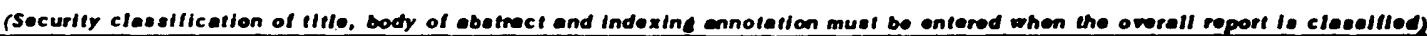

1. ORIGINATING ACTIVITY (Comorate outhor)

U. S. Army Cold Regions Research and

Engineering Laboratory

Hanover, New Hampshire 03755

S. REPORT TITLE

A RATIONAL APPROACH TO THE DESIGN OF AERATED SEW AGE LAGOONS

4. DESCRIPTIVE NOTES (TYPe of ropert and Incluelve datea)

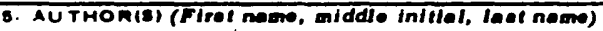

Edward F. Pohl

6. MEPORT DATE
OCtObET 1970
G. CONTAACT OR GRANTNO.
b. PROJECT NO.
c. DA Task 1T062112A13001
d.

\begin{tabular}{|l|l|}
\hline 70. TOZ 25 NO. OF PAGES & 7b. NO. 24 REFS \\
\hline OQ. ORIGINATOR'S REPOAT NUMEER(S)
\end{tabular}

10. DISTRIOUTION STATEMENT

This document has been approved for public release and sale; its distribution is unlimited.

The use of aerated lagoons as an economical sewage treatment system is a recently developed concept. Its adaptability to arctic and subarctic environments has been established through test programs in Alaska. This report summarizes current developments and discusses the physical and biochemical parameters which must be considered during design.

14. Key Words

Biochemical oxygen demand

Lagoons (ponds)

Sewage treatment 